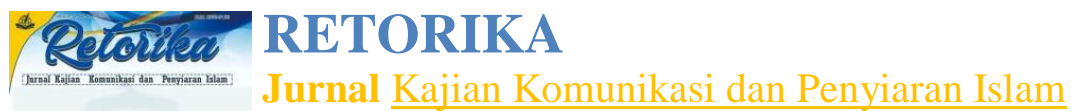

Volume 2, No. 1, 2020

P-ISSN: 2655-5166

E-ISSN: 2715-2103

(1) Homepage : http://journal.iaimsinjai.ac.id/indeks.php/retorika

\title{
KOMUNIKASI EFEKTIF DALAM ORGANISASI
}

\author{
Asriadi $^{1}$ \\ ${ }^{1}$ Institut Agama Islam Muhammadiyah Sinjai \\ E-mail: asriadiaccy92@gmail.com, Tlp:+6285343688717
}

\begin{abstract}
Abstrak
Komunikasi adalah instrumen yang digunakan manusia dalam berinteraksi dengan sesama, baik dalam kehidupan sehari-hari maupun dalam kehidupan berorganisasi. Dalam organisasi komunikasi merupakan alat yang berfungsi sebagai penghubung serta pembangkit motivasi antar setiap anggota sehingga sebuah organisasi dapat berjalan maju. Proses komunikasi yang efektif merupakan syarat terbinanya kerja sama yang baik untuk mencapai tujuan organisasi. Terdapat dua aspek penting yang mempengaruhi efektivitas komunikasi organisasi. Pertama, masalah proses pengolahan informasi dalam organisasi, yaitu menyangkut masalah pemaknaan pesan (informasi) dan jumlah informasi; kedua, masalah gaya komunikasi organisasi. Pemahaman kedua hal tersebut menjadi bekal bukan saja bagi para (calon) pemimpin organisasi, manajer, akan tetapi juga bagi semua yang terlibat dalam organisasi. Kegagalan komunikasi adalah menjadi pertimbangan terpenting dari setiap proses komunikasi organisasi, dengan maksud dapat diprediksi, dianalisis, dan ditanggulangi jika hal itu terjadi.
\end{abstract}

\section{Kata Kunci : Komunikasi Efektif, Proses Komunikasi, Komunikasi Organisasi, Elemen Komunikasi, Gaya Komunikasi.}

\section{Pendahuluan}

Sebagai makhluk sosial manusia senantiasa ingin berhubungan dengan manusia lainnya. Ingin mengetahui lingkungan sekitarnya, bahkan ingin mengetahui apa yang terjadi dalam dirinya. Rasa ingin tahu ini memaksa manusia perlu berkomunikasi. Menurut Dr. Everret Kleinjan dari East West Center Hawaii, komunikasi sudah merupakan bagian kekal dari kehidupan manusia seperti halnya bernafas. Sepanjang manusia hidup maka ia perlu berkomunikasi (Hafied Cangara, 1998:1).

komunikasi itulah yang menentukan kedinamisan suatu organisasi: Komunikasi merupakan kekuatan utama dalam membentuk organisasi dan komunikasi yang membuat dinamis suatu sistem kerjasama dalam organisasi dan menghubungkan tujuan organisasi pada partisipasi orang di dalamnya (Barnard, 1958: 175-181). 
Returea RETORIKA

Jurmal Kajian Komunikasi dan Penyiaran Islam

Volume 2, No. 1, 2020

P-ISSN: 2655-5166

E-ISSN: 2715-2103

(6) Homepage : http://journal.iaimsinjai.ac.id/indeks.php/retorika

Organisasi dapat diartikan sebagai suatu sistem individu yang relatif stabil yang bekerja sama untuk mencapai tujuan bersama melalui struktur hierarki dan pembagian kerja. Tata hubungan di antara anggota organisasi relatif stabil; kestabilan susunan organisasi menjadikan organisasi berfungsi secara efektif dalam mencapai tujuannya. Susunan organisasi dapat meramalkan komunikasi di antara anggotanya dan karenanya mempermudah tercapainya tujuan organisasi tersebut (Rogers,1976:6).

Dalam konteks organisasi para pengirim pesan - dalam hal ini katakanlah seorang pemimpin - ingin agar penerima pesan menyambut baik pesan komunikasi mereka sehingga kerja sama dan motivasi dapat ditingkatkan. Demikian juga halnya, para pengirim pesan menginginkan suatu umpan balik untuk mengetahui seberapa baik pemahaman pesan dan bagaimana pemanfaatannya. Meskipun pihak penerima pesan dan umpan balik tidak terlalu esensial dalam suatu komunikasi, namun hal tersebut penting bagi hubungan kerja yang efektif secara jangka panjang. Dari sisi penerima pesan, bagaimana agar suatu pesan dapat difahami dan ditanggapi dengan baik, dimanfaatkan, serta memberi umpan balik kepada pengirim pesan sehingga komunikasi menjadi efektif. Apabila komunikator menyampaikan pesan dan penerima pesan memberikan umpan balik kepada pihak pengirim, maka hal ini boleh dikatakan telah terjadi komunikasi dua arah yang efektif. Suatu putaran komunikasi yang berjalan tuntas, maka pesan mengalir dari pengirim kepada penerima pesan dan kembali kepada pengirim pesan dalam proses komunikasi.

Salah satu aspek yang penting dalam pelaksanaan pelayanan public atau efektifnya berkomunikasi adalah kemampuan seorang pemimpin dalam berinteraksi dan berkomunikasi dengan orang lain karena komunikasi adalah hal yang paling lumrah dilakukan dalam orang memberikan layanan. Bukanlah suatu bentuk penyederhanaan jika hanya terdapat dua permasalahan utama dari proses komunikasi organisasional yang menentukan organisasi berjalan efektif, yaitu pertama, proses pengolahan pesan (informasi), dan kedua, gaya komunikasi organisasional. Proses pengolahan informasi yang terutama adalah proses pemaknaan dan jumlah muatan informasi itu. Proses pemaknaan adalah bagaimana suatu pesan yang diterima 
"Retorra RETORIKA

Jurmal Kajian Komunikasi dan Penyiaran Islam

Volume 2, No. 1, 2020

P-ISSN: 2655-5166

E-ISSN: $2715-2103$

(옹 Homepage : http://journal.iaimsinjai.ac.id/indeks.php/retorika

individu yang terlibat dalam organisasi diartikan menurut persepsinya. Pesan tidak memiliki arti apa-apa jika orang yang terlibat komunikasi (peserta komunikasi) tidak memberi makna yang sama terhadap pesan tersebut. Dengan kata lain, arti suatu pesan tidak terletak pada pesan itu sendiri, akan tetapi pada orang yang menerima dan menyampaikan pesan (word doesn't mean, but people mean). Suatu instruksi (atasbawah) atau laporan (bawah-atas) akan bermakna jelas jika orang yang menerima informasi itu memberi makna sama seperti orang yang menyampaikan pesan tersebut. Permasalahan timbul jika ada perbedaan pemaknaan antara pemberi dan penerima pesan.

\section{Kajian Teori}

\subsection{Organisasi}

Menurut Lubis dan Husaini (1987) bahwa yang dimaksud dengan organisasi adalah sebagai suatu kesatuan sosial dari sekelompok manusia, yang berinteraksi menurut suatu pola tertentu sehingga setiap anggota organisasi memiliki fungsi dan tugasnya masing- masing, yang sebagai satu kesatuan mempunyai tujuan tertentu dan mempunyai batas-batas yang jelas, sehingga bisa dipisahkan secara tegas dari lingkungannya.

Menurut Sutarto (1985) bahwa organisasi adalah sistem yang saling berpengaruh antar orang dalam kelompok yang bekerjasama untuk mencapai tujuan tertentu. Menurut Herbert and Gullet bahwa yang dimaksud dengan pengorganisasian merupakan proses yang mana struktur suatu organisasi dibuat dan ditegakan. Proses ini meliputi ketentuan dari kegiatan-kegiatan yang spesifik yang perlu untuk menyelesaikan semua sasaran organisasi, pengelompokan kegiatan tersebut berkaitan dengan susunan yang logis, dan tugas dari kelompok kegiatan ini bagi suatu jabatan atau orang yang bertanggung jawab.

Barnard berpendapat bahwa organisasi adalah suatu sistem aktivitas kooperatif antara dua orang atau lebih. Organisasi merupakan pengelompokan orang-orang ke dalam aktivitas kerjasama untuk mencapai tujuan yang telah ditetapkan, sedangkan 
Retorra RETORIKA

Jurmal Kajian Komunikasi dan Penyiaran Islam

Volume 2, No. 1, 2020

P-ISSN: 2655-5166

E-ISSN: 2715-2103

Q

Homepage : http://journal.iaimsinjai.ac.id/indeks.php/retorika

pengorganisasian adalah aktivitas orang-orang dalam mengelompokan, menyusun dan mengatur berbagai macam pekerjaan yang perlu diselenggarakan untuk mencapai tujuan pendidikan dalam (Henry Fayol, 1974). Organisasi merupakan penugasan orang-orang ke dalam fungsi pekerjaan yang harus dilakukan agar terjadi aktivitas kerjasama dalam mencapai tujuan. Sedangkan pengorganisasian merupakan penyusunan dan pengelompokan bermacam-macam pekerjaan berdasarkan jenis pekerjaan, urutan sifat dan fungsi pekerjaan, waktu dan kecepatan (Griffin: 1959).

Proses pengorganisasiaan akan menghasilkan organisasi. Pengorganisasian adalah sebuah proses dan aktivitas/kegiatan. Walaupun organisasi memiliki struktur namun bagaimana organisasi bertindak dan bagaimana organisasi tersebut tampil ditentukan oleh struktur yang ditetapkan oleh pola-pola reguler perilaku yang saling bertautan. (Weick, 1979, 90).

Pengorganisasian adalah suatu gramatika (aturan, konvensi, praktik organisasi) yang disahkan secara mufakat untuk mengurangi ketidakpastian dengan menggunakan perilaku bijaksana (pengalaman) yang saling bertautan. pengalaman dilalui bersama dengan orang lain melalui sistem lambang/simbol. Proses/tahap pengorganisasian, tahap enactment secara sederhana berarti bahwa paraanggota organisasi menciptakan ulang lingkungan mereka dengan menentukan dan merundingkan makna khusus bagi suatu peristiwa, Tahap seleksi, aturan-aturan dan siklus komunikasi digunakan untuk menentukan pengurangan yang sesuai dengan ketidakjelasan dan Tahap retensi,memungkinkan organisasi menyimpan informasi mengenai cara organisasi itu memberi respon atas berbagai situasi.

\subsection{Komunikasi}

Komunikasi terdengar mudah dilakukan dan setiap orang menganggap bahwa mereka bisa melakukannya. Tetapi komunikasi yang seperti apakah yang dianggap sebagai komunikasi yang efektif? Setiap aktivitas komunikasi sehari-hari biasanya tidak terstruktur, sehingga peran komunikator menjadi tumpang tindih. Hal itu berakibat pula pada makna dari komunikasi yang dilakukan. 
Retortea RETORIKA

Jurmall Kajian Komunikasi dan Penyiaran Islam

Volume 2, No. 1, 2020

P-ISSN: 2655-5166

E-ISSN: $2715-2103$

(6) Homepage : http://journal.iaimsinjai.ac.id/indeks.php/retorika

Komunikasi pada umumnya didefinisikan sebagai kegiatan saling bertukar pendapat, atau hubungan antara manusia, baik individu maupun kelompok. Komunikasi manusia merupakan proses pembentukan makna di antara dua orang atau lebih. Dari pernyataan ini maka komunikasi berhubungan dengan makna yang dapat diperoleh diantara pihak-pihak yang melakukan komunikasi.

Menurut A.W. Wijaya (2000: 15) komunikasi adalah penyampaian informasi dan pengertian dari seseorang kepada orang lain. komunikasi akan dapat berhasil apabila sekiranya timbul saling pengertian, yaitu jika kedua belah pihak, si pengirim dan si penerima informasi dapat memahaminya. Hal ini tidak berarti bahwa kedua belah pihak harus menyetujui sesuatu gagasan tersebut, tetapi yang penting adalah kedua belah pihak sama- sama memahami gagasan tersebut. Dalam keadaan seperti inilah baru dapat dikatakan komunikasi telah berhasil baik (komunikatif).

Selain proses pemaknaan pesan yang akan menentukan perilaku hubungan komunikator dan komunikate di dalam organisasi, jumlah pesan akan menentukan juga perilaku orang yang terlibat dalam proses komunikasi organisasi tersebut. Informasi yang berlebihan (information overload) akan dapat menimbulkan reaksi negatif dari peserta komunikasi. Miller (1956: 81-97) menyebutkan, ada tujuh reaksi orang terhadap kelebihan informasi ini:
a. Gagal dalam memperhitungkan informasi
b. Banyak membuat kesalahan
c. Menunda atau menumpuk pekerjaan (de-laying or queueing).
d. Penyaringan (filtering).
e. Menangkap informasi secara garis besar
f. Menugaskan atau melemparkan tugas kepada orang lain
g. Menghindari informasi yang datang.

\subsection{Elemen-Elemen Komuniksi}

Dari uraian elemen-elemen dasar diatas penulis mengambil dasar sebagai dasar atau acuan yang harus di perhatikan ataupun di teiiti sebagai sumber atau objek penelitian dalaam proses komunikasi nonverbal yaitu sebagai berikut: 
Retorra RETORIKA

Jurmal Kajian Komunikasi dan Penyiaran Islam

Volume 2, No. 1, 2020

P-ISSN: 2655-5166

E-ISSN: $2715-2103$

(6) Homepage : http://journal.iaimsinjai.ac.id/indeks.php/retorika

1. Sumber (komunikator

Semua peristiwa komunikasi akan melibatkan sumber sebagai pengirim inforrnasi. Sumber bisa terdiri dari satu orang atau kelompok, misalnya partai, oraganisasi atau lembaga. Dalam hal ini, sosialisasi akan efektif jika seorang komunikator memiliki stratcgi dalam penyampaia informasi/pesan baik sccara verbal maupun nonverbal kepada sasaran. Strategi komunikasi yang baik, dapat mempengaruhi audiens atau sasaran komunikasi dalam prosos sosialisasi yang dilakukan.

2. Pesan

Pesan adalah sesuatu (pengetahuan, híburan, informasi, nasehat atau propaganda) yang disampaikan pengirim kepada peneríma. Pesan dapat disampaikan dengan cara tatap muka atau melalui media komunikasi. Duncan menyebutkan enam jenis pesan nonverbal dalam bukunya Jalaludin Rakhmat Psikologi Koinuníkasi, ia mengelompokan pesan-pesan nonverbal yaitu kinestl atau gerakan tubuh, Paralinguistik atau suara, prosemik atau penggunaan ruangan personal dan sosial, olfaksi atau pemicu, sensitivitas kulit dan factor artifaktual seperti pakaian dan komestik (Jalaluddin, 2011: 285)

a) Pesan kinestik menggunakan gerakan tubuh yang terdiri dari empat komponen yaitu; pesan fasial, pesan gestural, pesan postural dan pesan proksemik.

2) Pesan Fasial menggunakan air muka untuk menyampaikan makna tertentu. Berbagai penelitian menunjukkan bahwa wajah dapat menyampaikan paling sedikit sepuluh kelompok makna kebahagiaan, rasa terkejut, ketakutan, kemarahan, kesedihan, kemuakan, pengecaman, minat, ketakjuban dan tekad.

3) Pesan Gestural menunjukkan gerakan sebagian anggota badan seperti mata dan tangan untuk mengkomunikasikan berbagai makna.

4) Pesan Postural berkenaan dengan keseluruhan anggota badan. Menurut 
Volume 2, No. 1, 2020

P-ISSN: 2655-5166

E-ISSN: $2715-2103$

Homepage : http://journal.iaimsinjai.ac.id/indeks.php/retorika

mehrabian menyebutkan tiga makna yang dapat disampaikan. Pertama, immediacy yaitu ungkapan kesukaan den ketidaksukaan terhadap individu yang lain. Postur yang Condong ke arah yang diajak bicara menunjukkan kesukaan dan penilaian positif. Kedua Power, mengungkapkan status yang tinggi pada diri komunikator. Anda dapat membayangkan postur orang yang tinggi hati di depan anda dan postur orang yang merendah.bKetiga Responsiveness, individu dapat bereaksi secara emosional pada lingkungan secara positif dan negatif. Bila postur anda tidak berubah, anda mengungkapkan sikap yang tidak responsif (Jalaluddin, 2011: 285- 286)

b) Pesan paralinguistik adalah pesan nonverbal yang berhubungan degan cara mengucapkan pesan verbal. Suatu pesan verbal yang sama dapat menyampaikan arti yang berbeda bila diucapkan secara berbeda. Pesan ini oleh deddy mulyana disebutnya sebagai para bahasa (Jalaluddin, 2011: 288)

c) Pesan Proksemik disampaikan melalui pengaturan jarak dan ruang. Umumnya dengan mengatur jarak kíta mengungkapkan keakraban kita dengan orang lain (Jalaluddin, 2011: 286)

d) Olfaksi atau pemicu adalah the most experienced of sense. Penglihatan tidak berfungsi ketika tidak ada cahaya. Telinga boleh mendengarkan, tetapi tidak mendengar. Indera perasaan seringkali tidaak bekerja. Namun, indera pemicu bekerja setiap saat.

e) Sensitivitas kulit, alat penerima sentuhan adalah kulit, yang mampu menerima dan membedakan berbagai emosi yang disampaikan orang melalui sentuhan. Smith melaporkan berbagai perasaan yang dapat disampaikan sentuhan, tetapi yang paling bisa di komunikasikan sentuhan ada lima; tanpa perhatian, kasih sayang, takut, marah dan bercanda.

f) Factor artifaktual ungkapkan melalui penampilan tubuh, pakaian dan kosmetik. Walaupun bentuk tubuh relatif menetap, orang sering berprilaku dalam hubungan dengan orang lain sesuai dengan persepsinya tentang 
Returea RETORIKA

Jurmal Kajian Komunikasi dan Penyiaran Islam

Volume 2, No. 1, 2020

P-ISSN: 2655-5166

E-ISSN: $2715-2103$

(9) Homepage : http://journal.iaimsinjai.ac.id/indeks.php/retorika

tubuhnya (body image). Erat kaitannya dengan tubuh ialah upaya kita membentuk citra tubuh dengan pakaian dan kosmetik (Jalaluddin, 2011: 288). Deddy mulyana dalam bukunya berpendapat bahwa aspek ini merupakan perluasan lebih jauh dari pakaian dan penampilan melainkan benda-benda yang digunakan untuk memenuhi kebutuhan hidup manusia dan dalam interaksi manusia, sering mengandung makna-makna tertentu. Bidang studi mengenai hal ini disebut objektika (Objectics) (Deddy Mulyana, 2017: 433)

3. Saluran (media)

Saluran atau channel adalah jalan yang dilalui pesan untuk sampai kepada penerima (Morissan, 2014: 20).

4. Penerima (komunikan)

Penerima atau receiver atau juga disebut audiens adalah saluran atau target dari pesan. Penerima sering pula disebut komunikan. Penerima dapat berupa individu, satu kelompok, lembaga atau bahkan suatu kumpulan besar manusia yang tidak saling menganal (Morissan, 2014: 22). Jadi penerima atau audiens adalah pihak yang menjadi sasaran pesan yang dikirim oleh pengirim (komunikator).

5. Efek (dampak)

Efek adalah unsur penting dalam keseluruhan proses komunikasi. Efek bukan hanya sekedar umpan balik dan reaksi penerima (komunikan) terhadap pesan yang dilontarkan oleh komunikator melainkan efek dalam komunikasi merupakan panduan sejumlah ikekuatanl yang bekerja dalam masyarakat, di mana komunikator hanya dapat menguasai satu kekuatan saja, yaitu pesanpesan yang dilontarkan. Bentuk konkrit dalam komunikasi adalah terjadinya perubahan berpendapat atau sikap atau prilaku khalayak, akibat pesan yang menyentuhnya. Hal ini menyangkut proses komunikasi yang asasi sifatnya (Muhammad saleh, 2011:80). 
Retortea RETORIKA

Jurmal Kajian Komunikasi dan Penyiaran Islam

Volume 2, No. 1, 2020

P-ISSN: 2655-5166

E-ISSN: 2715-2103

(9) Homepage : http://journal.iaimsinjai.ac.id/indeks.php/retorika

Elemen-elemen komunikasi tersebut diatas mengelompokkan unsur-unsur dari proses komunikasi nonverbalnya. Mulai dari apa atau siapa sumbernya, bagaimana pesannya. Apa salurannya, siapa penerimanya, bagaimana efeknya atau dampak dari hasil penyampaian pesan komunikator pada audiens. Dari uraian diatas adalah gambaran skema atau alur proses komunikasi.

Apabila di gambarkan skema komunikasi model Lasswell bekerja dapat di lihat sebagai berikut ini (Werner, 2008:38):

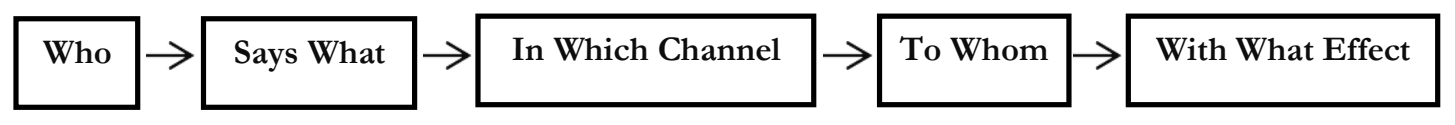

\section{Gambar : Model Lasswell}

Gambar diatas memberikan penjelasan bagaimana komunikasi dapat bekerja secara sistematis sehingga hasilnya tepat sasaran. Lima unsur itu merupakan elemen pokok komunikasi yang sangat penting dan tidak boleh di tinggalkan dalam melakukan komunikasi dengan siapa saja termasuk dalam komunikasi nonverbal.

\section{Pembahasan}

\subsection{Komunikasi dalam Organisasi}

Dalam kehidupan sehari-hari pastinya seseorang berhubungan dengan masyarakat. Dalam hal itu tujuannya yaitu untuk menyampaikan informasi dan mencari informasi kepada meraka, agar apa yang ingin disampaikan atau yang diminta dapat dimengerti sehingga komunikasi dapat berjalan lancar. Setiap kali berkomunikasi maka seseorang harus menentukan tujuan dari komunikasi tersebut, tujuan tersebut dapat dikategorikan menjadi beberapa hal, yaitu:

1. Menjelaskan sesuatu kepada orang lain, yang dimaksudkan yaitu menginkan supaya orang lain mengerti dan dapat memahami apa yang dimaksudkan.

2. Bila ingin orang lain menerima dan mendukung gagasan yang dimaksudkan. 
Returea RETORIKA

Jurmal Kajian Komunikasi dan Penyiaran Islam

Volume 2, No. 1, 2020

P-ISSN: 2655-5166

E-ISSN: $2715-2103$

(9) Homepage : http://journal.iaimsinjai.ac.id/indeks.php/retorika

Yaitu dengan pendekatan persuasif, bukan dengan cara memaksakan kehendak.

3. Menggerakkan orang lain untuk melakukan sesuatu.

Jadi secara singkat dapat dikatakan bahwa komunikasi itu bertujuan mengharapkan pengertian, dukungan gagasan dan tindakan.

Goldhaber (1993: 14-15) juga mengemukakan bahwa komunikasi organisasi dapat di definisikan dari berbagai sudut pandang, seperti yang berikut ini;

1. Komunikasi organisasi terjadi dalam suatu sistem terbuka yang kompleks yang dipengaruhi oleh lingkungannya, baik internal (yang disebut budayanya) dan eksternal.

2. Komunikasi organisasi melibatkan pesan dan saluran, tujuan, arah dan media.

3. Komunikasi organisasi melibatkan orang-orang dan sikap mereka, perasaan dan hubungan dan keterampilan.

4. Komunikasi organisasi adalah proses menciptakan dan saling menukar pesan dalam satu jaringan hubungannya yang saling tergantung satu sama lain untuk mengatasi lingkungan yang tidak pasti atau selalu berubah-ubah.

Tujuan komunikasi organisasi adalah, untuk memudahkan, melaksanakan, dan melancarkan jalannya organisasi. Menurut Koontz (dalam Moekijat, 1993: 15-16), dalam arti yang lebih luas, tujuan komunikasi organisasi adalah untuk mengadakan perubahan dan untuk mempengaruhi tindakakan ke arah kesejahteraan perusahaan. Sementara itu, Lliliweri (2013: 372-373) menyatakan bahwa ada empat tujuan komunikasi organisasi, yaitu;

1. Menyatakan pikiran, pandangan dan pendapat

2. Membagi informasi

3. Menyatakan perasaan dan emosi

4. Melakukan koordinasi

Dalam proses komunikasi organisasi, ada beberapa komponen penting untuk diperhatikan, yaitu;

1. Jalur komunikasi internal, eksternal, atas-bawah, bawah-atas, horizontal, serta jaringan. 
Retortea RETORIKA

Jurmal Kajian Komunikasi dan Penyiaran Islam

Volume 2, No. 1, 2020

P-ISSN: 2655-5166

E-ISSN: 2715-2103

(3) Homepage : http://journal.iaimsinjai.ac.id/indeks.php/retorika

2. Induksi, antara lain orientasi tersembunyi dari para karyawan, kebijakan dan prosedur, serta keuntungan para karyawan.

3. Saluran, yang diantaranya media elektronik (email, internet), media cetak dan tatapmuka.

4. Rapat, antara lain briefing, rapat staf, rapat proyek dan dengan pendapat umum.

5. Wawancara, antara kain seleksi, tampilan kerja dan promosi karier.

\subsection{Metode dan Media dalam Berkomunikasi}

Metode dan media yang digunakan oleh organisasi dalam memberikan informasi memberikan kontribusi terhadap informasi yang dihasilkan dalam melakukan komunikasi, semuanya harus disesuaikan dengan isi pesan yang akan disampaikan. Cara komunikasi yang digunakan untuk menyampaikan pesan harus disesuaikan dengan isi pesan. Hal ini akan mengurangi risiko terjadinya kesalahkaprahan pesan yang disampaikan. Metode komunikasi terdiri dari verbal (lisan dan tertulis komunikasi ) dan non verbal. Organisasi menggunakan berbagai bentuk komunikasi non verbal . Metode non verbal bisa memiliki efek yang kuat. Misalnya, ruang tunggu yang dirancang dengan baik dansenyum yang ramah, cerdas, kemudian juga staf yang berpakaian rapi cenderung memiliki pengaruh positif pada calon pelanggan, hal ini akan menampakkan tentang adanya "profesionalisme" dan layanan pelanggan (Blundel, 2004:75)

Pada komunikasi verbal, jika pesan harus melalui banyak orang kemungkinan distorsi pada pesan yang disampaikan akan cukup besar (Robbins , 2007: 396). Sementara komunikasi tertulis adalah pesan yang dikemas dalam laporan organisasi, surat, buletin yang biasanya menyertakkan perintah kerja, kebijakan dan sebagainya. Komunikasi tertulis sangat berguna untuk komunikasi yang kompleks dan panjang. Keuntungan dari metode komunikasi ini adalah pesan dapat disimpan dalam jangka panjang dan sekaligus bisa menjadi bukti. Meski demikian, metode ini memiliki kelemahan pada proses yang memakan waktu, biaya yang besar, serta umpan balik pesan yang tidak dapat segera diterima. Dalam menyampaikan pesan, mengetahui efektivitas media sebagai saluran pesan sangat penting. Media komunikasi memiliki 
Retorra RETORIKA

Jurmal Kajian Komunikasi dan Penyiaran Islam

Volume 2, No. 1, 2020

P-ISSN: 2655-5166

E-ISSN: 2715-2103

(옹 Homepage : http://journal.iaimsinjai.ac.id/indeks.php/retorika

kapasitas yang berbeda dalam menyampaikan informasi. Menurut Robbins ( 2007; 406 ), ada beberapa media yang memiliki kemampuan untuk menangani berbagai tanda secara bersamaan, memfasilitasi umpan balik yang cepat dan personal. Namun ada media lain yang tidak memiliki ketiga faktor di atas. Berikut adalah berbagai media yang memiliki banyak saluran sampai pada media yang memiliki sedikit saluran ( Robbins, 2007: 407 ).

a) percakapan tatap muka dan video conference

b) pidato dan percakapan melalui telepon

c) voice mail dan kelompok diskusi online

d) rekaman pidato dan Email

e) Format laporan dan bulletin seperti memo atau surat.

Sebuah media yang baik adalah media yang memungkinkan setiap anggotanya terlibat dalam pengiriman pesan untuk menangani langsung pertemuan organisasi atau video konferensi. Hal ini karena jumlah informasi selama komunikasi yang akan diberikan maksimum dan umpan balik pada pesan yang disampaikan dapat segera diperoleh.

\subsection{Komunikasi yang efektif dalam Organisasi}

Morissandalam bukunya menyatakan bahwa percakapan merupakan bagian dari kehidupan manusia yang alami (karena tidak dapat menghidarkan percakapan), namun percakapan bukanlah sesuatu yang tanpa konsekuensi. Percakapan yang kita lakukan membentuk siapa dan bagaimana diri kita sebagai individu dan debagai anggota masyarakat (Asriadi, 2019).

Setiap informasi bersifat arbriter (dimaknai sesuka hati), maka dalam proses komunikasi organisasi yang penting adalah bagaimana membuat makna dari suatu informasi sama di antara pemberi informasi dan penerima informasi. Komunikasi efektif jika maksud pengirim pesan dimaknai sama oleh penerima pesan. Goyer (dalam Tubbs dan Moss, 2000:22) menuliskan rumus komunikasi efektif: 
Returea RETORIKA

Jurmal Kajian Komunikasi dan Penyiaran Islam

Volume 2, No. 1, 2020

P-ISSN: 2655-5166

E-ISSN: 2715-2103

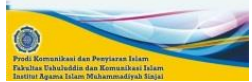

Homepage : http://journal.iaimsinjai.ac.id/indeks.php/retorika

$\mathrm{R}$ makna yang ditangkap penerima

$-\quad=$

S

makna yang dimaksud pengirim

Nilai efektivitas komunikasi dikatakan sempurna jika perbandingan makna yang dimaksud pengirim (S) dengan makna yang ditangkap penerima (R) sama dengan satu. Tetapi, menurut Goyer, kondisi itu — sangat jarang, dan palingpaling mendekati saja. Rasio yang melebihi atau kurang dari angka satu disebabkan oleh Ketidaksamaan pengertian (pemaknaan) antara pengirim dan penerima informasi, dan kondisi ini disebut sebagai kegagalan komunikasi.

Dalam teori komunikasi, kegagalan komunikasi ada dua tingkat, yaitu kegagalan komunikasi primer dan sekunder. Kegagalan komunikasi primer terjadi bila terdapat salah persepsi (pemaknaan) pesan. Misalnya, dalam suatu organisasi, pesan formal seorang atasan yang menginstruksikan sekretarisnya untuk pergi kerja lembur ke luar kota. Sang sekretaris menggigil ketakutan membayangkan pekerjaan yang akan dilakukannya dengan sang boss (karena ia baru seminggu bekerja), atau sang sekretaris akan menjerit girang (karena sudah lama ia naksir sang boss). Padahal yang dimaksud atasannya tersebut adalah sekretaris pergi sendirian ke luar kota dengan biaya penuh dari perusahaan.

Kegagalan komunikasi sekunder terjadi jika bukan saja terdapat salah persepsi, akan tetapi jika sampai terjadi kerenggangan (bahkan terputusnya) hubungan sosial. Dalam komunikasi terdapat konsep —orang berbicara bukan saja menyampaikan pesan, tetapi juga menyampaikan dirinya. Jadi setiap proses komunikasi, berlangsung juga proses hubungan antarpribadi. DeVito (1989:26) menyebutnya communication has content and relationship dimensions. 
"Retortra RETORIKA

Jurmal Kajian Komunikasi dan Penyiaran Islam

Volume 2, No. 1, 2020

P-ISSN: 2655-5166

E-ISSN: 2715-2103

(6) Homepage : http://journal.iaimsinjai.ac.id/indeks.php/retorika

\section{PENUTUP}

Mengenal gaya komunikasi organisasi adalah langkah awal untuk mengetahui budaya organisasi/perusahaan. Bersama-sama dengan proses pengolahan informasi berupa pemaknaan dan jumlah informasi, gaya komunikasi menentukan efektivitas komunikasi organisasional. Hal itu perlu dipertimbangkan; sebab, pertama, manajemen perlu diyakinkan kembali bahwa komunikasi merupakan faktor terpenting dari organisasi yang menentukan kedinamisan organisasi dan menentukan keberhasilan organisasi; kedua, perlu dipikirkan melakukan rekayasa komunikasi yang baik, sejak organisasi dibentuk; ketiga, manajemen perlu mempertimbangkan kelebihan dan kekurangan, dukungan, dan hambatan proses komunikasi dalam menentukan setiap langkah jalannya organisasi; keempat, menempatkan organisasi sebagai sebuah wahana sekumpulan orang dengan menciptakan iklim saling menghargai secara manusiawi. Kegagalan komunikasi adalah kondisi yang harus dihindari dalam setiap proses komunikasi. Kalaupun terjadi, yang terpenting adalah —Tidak ada yang paling buruk kecuali ketidakpedulian, dan tidak ada yang paling baik selain dihargainya perbedaan pendapat.

\section{DAFTAR PUSTAKA}

A.W.Wijaya. 2000. Ilmu Komunikasi Pengantar Studi, Jakarta: Rineka Cipta

Asriadi, A. (2019). Komunikasi Antar Budaya dalam perspektif Al-Qur'an Surat AlHujurât Ayat 13. RETORIKA: Jurnal Kajian Komunikasi Dan Penyiaran Islam, $1(1)$, $38-50$.

http://journal.iaimsinjai.ac.id/index.php/retorika/article/view/333/259.

Barnard, Chester I. 1958. The Function of The Executive, Harvard Cam bridge Mass. Cangara Hafied, 1998. Pengantar Ilmu Komunikasi, Jakarta: PT RajaGrafindo.

Deddy Mulyana, 2017. Ilmu Komunikasi Suatu Pengantar, Bandung; Remaja Rosdakarya. DeVito, Joseph A. 1989. The Interpersonal Communication Book, fifth ed.,New York, Harper \&

Effendi Onong Uchjana, 1990. Ilmu Komunikasi Teori dan Praktek, Bandung: PT Remaja Rosdakarya.

Hall, Edward T. 1959. The Silent Language, New York:Fawcett World Library. Hick, Herbert, G. and Gullet, G. Ray, 1975. Organization Theory and Behavior. 
Volume 2, No. 1, 2020

P-ISSN: 2655-5166

E-ISSN: $2715-2103$

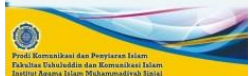

Homepage : http://journal.iaimsinjai.ac.id/indeks.php/retorika

Terjemahan Ali Saefullah. Usaha Nasional: Surabaya.

Jalaluddin Rakhmat, 2011. Psikologi Komunikasi, Bandung; Remaja Rosdakarya.

Lubis, Hari \& Huseini, Martani, 1987. Teori Organisasi; Suatu Pendekatan Makro.

Pusat Antar Ilmu-ilmu Sosial UI: Jakarta

Miller, G. 1956. —The Magical Number 7, 1956. "Plus or Minus Two: Some Limits on Our Capacity for Processing Information, Psychological Review'

Morissan, 2014. Teori Komunikasi Individu Hingga Massa, Jakarta; Kencana.

Muhammad saleh, 2011. Efektivitas Komunikasi nonveral dalam pelestarian Syariat Islam di kota Lhokseumawe, Tesis Medan; IAIN Sumatra Barat.

Rogers Everett M., \& Rekha Agarwala Rogers, 1976. Communication in Organization, New York, The Free Press.

Row Publisher.

Sutarto, 1985. Dasar-dasar Organisasi, Gadjah Mada University: Yogyakarta.

terjemahan cetakan kedua, Bandung, PT. Rosda.

Tubbs, Stewart.L. Sylvia Moss, 2000. Human Communication: Konteks-konteks Komunikasi,

Werner J. Severin, James W. Tankard, Jr, 2008. Teori Komunikasi: Sejarah, Metode dan Terapan di Media Massa, Jakarta; Kencana.

Yoshikawa, Moneo Jay. 1988. - Japanese and American Modes of Communication and Implication for Managerial and Organizational Behavior, dalam Wimal Dissanayake (ed.) Communication Theory The Asian Perspective, AMIC, Singapore. 